\title{
IMPACT OF INDUSTRIAL EXPOSURE TRAINING ON CAREER AND STUDENT SATISFACTION. A CASE STUDY OF STUDENTS STUDYING IN CENTRAL IHM'S
}

\author{
Javaid Ahmad Bhat \\ Research Scholar in Hospitality, \\ Department Amity School of Hospitality, Amity University Rajasthan, India
}

Dr Sushil Kumar*

Assistant Professor, Amity School of Hospitality, Amity University Rajasthan, India

*Corresponding Author

\begin{abstract}
India has a rich heritage of culture and history, attraction of which has resulted in high tourist flow. This increasing ratio of tourism has given an impetus to the growth of hotel industry and the program of hotel management at higher level education got a huge importance amongst other educational courses. The report of World Travel and Tourism Council explained the importance of tourism in India with data as "Tourism in India is important for the country's economy and is growing rapidly. The World Travel and Tourism Council submitted that tourism contributed to GDP and supported millions of its total employment. The sector is further predicted to grow at an annual rate of $6.9 \%$ to ₹32.05 lakh crore (US\$450 billion) by 2028 (9.9\% of GDP). "It means good jobs are on offer for the Hotel Management students immediately after graduating from the colleges. While framing the curriculum for these courses, the policy makers have been kind enough to make Internship/Industrial Exposure Training as an integral part of the Hospitality Education. Amoung many benefits IET helps students to develop competencies, get hands on experience, nurture their growth and makes them employable. It also enhances Industry Institute relationship and dare teaching faculty to impart up-to-date information to the students.

Current work is an attempt to find Impact of Industrial exposure Training on Student Satisfaction and subsequently on their career. The data has been collected through a structured questionnaire from students studying in Central Institutes of Hotel Management affiliated to National council for Hotel Management \& Catering Technology, Noida (India)
\end{abstract}

Key words: Internship, Students, tourism, India, economy, management, hotel etc 
Cite this Article: Javaid Ahmad Bhat and Sushil Kumar, Impact of Industrial Exposure Training on Career and Student Satisfaction. A Case Study of Students Studying in Central IHM's, International Journal of Management, 11(12), 2020, pp 2933-2938.

http://iaeme.com/Home/issue/IJM?Volume=11\&Issue=12

\section{INTRODUCTION}

India is rich in natural resources which is evident from the figures of millions of tonnes of export and ranks high in cultural resources and business travel in the world. But, another aspect of its business infrastructure poses a gap between supply and demand particularly in peak seasons. There is a shortage rooms per capita by international comparison and with foreign arrivals expected to rise there is a need to fill up the gap

With major budget allocation for the development of tourist circuits and reduction in GST on hotel rooms the industry is expected to grow rapidly. To manage this growth the demand for recent graduates is increasing. To satisfy the strain edifice faculties are answerable for providing ball-hawking hands. Like different skilled courses, edifice management students bear office in varied edifices to grasp concerning the operational skills that aren't potential in hotel faculties. However, it's quite evident that there's a distinction in their career expectation once they complete their office. The study aims to establish the variations in their perception concerning their career in the edifice trade. The study hopes to bring out the final opinion student show toward the welcome business in terms of the image hooked up to the trade and therefore the potential level of commitment these students can have in following a career once they graduate. A sample of edifice management students participated in this study. A form was administered to students. Queries were centred on the factors like operating conditions, learning opportunities, compensation that have an effect on career within the edifice trade. Students believe it to be a growing trade with huge opportunities for employment. The scholars World Health Organization had completed their coaching had an additional negative perspective towards the edifice trade. Similarly, level of commitment varied between pre and post coaching students with the scholars World Health Organization already completed their office showing less inclination to figure within the close to future within the trade. The analysis work can attempt to bring out the challenges that require to be self-addressed as edifice managements students are the key hands for the property of the trade.

Tourism in Asian country is very important for the country's economy and is growing rapidly. The sector generated ₹ 15.24 large integer large integer (US $\$ 210$ billion) or nine.4\% of India's value in 2017 and supported forty one.622 million jobs, 8 May 1945 of its total employment.

Based on the data collected the hospitality sector in India is expected to grow at 16.1 per cent CAGR to reach Rs 2,796.9 thousand crore in 2022. The hospitality sector encompasses a wide variety of activities within the services sector and is a major job provider both direct and indirectly.

\section{OBJECTIVES OF THE STUDY}

- To explore the factors that influence student's overall satisfaction with their internship experience and whether these factors affect their career.

- To identify the level of satisfaction of the students with their internship experience, the stakeholder that has the most influence over student's overall satisfaction.

- To collect data from Hotel Management students in studying in Central IHM's.

- To study the challenges during the internship experience in the course of hotel management. 
Hypothesis: It's not an easy to work in the field of hotel management as an internship student. Methodology of the Study: The present research is field work based work. Total 60 student of $3^{\text {rd }}$ year BSc H\&HA students in various Central IHM's were selected as sample size

Source of the Study: Two types of sources are used for current study as:

a. Primary Source: As a part of Primary resource of current work, 60 samples are selected from the hotel management college students of Central IHM's and questionnaire is given to them to fill. Result is analysed from the filled questionnaire of Sample.

b. The Secondary Source: Secondary source of the study is collected material within the kind of books, journals; article in written or revealed kind is employed as secondary supply of the study.

\section{LITERATURE REVIEW}

Mayo (1997) points that, as welcome is deeply frozen in action management, the business will need maintaining sure necessary skills within the info. Writer (1990) believes that even though teachers tend to promote the insertion of general management skills in the info, the business will not show explicit interest in the event of high order psychological feature skills. Rimmington (1999) argues that welcome course provides foundation, generic and transferable skills while the business can give the follow a part of the studies, which is doubly as necessary because it offers students the possibility to find out in reality and an amount of your time to replicate upon the truth of their studies. Writer and Nickson (1998) their study points that the greatest challenge is to notice the right balance in terms of stress to put on completely different talent sets. In reality, an excessive amount of stress on theory might leave students confused on the connectedness of their studies whereas an excessive amount of specialise in the sensible facet can leave them while not the mandatory skills to grasp the business. (Beggs, Ross, and Goodwin 2008) noted that place courses give learning opportunities for undergraduates to grasp skilled follow and activities related to information application. (Lam \& Ching, 2007) opines that place is associate degree integral a part of a student's career development and should have many positive impacts on students. Lyricist (1988) noted that place give graduates students with expertise in specific areas of career interest and ultimately increase their potential to possess a winning career. On the opposite hand educators believe that real life experiences and skilled development are the most useful aspects of the place for welcome students. Calloway \& Beckstead (1995) from the students' purpose of read, place helps to inform them with sensible skills, develop social relationships, inspire future learning and develop a socially acceptable temperament. Davies (1990) points that place may be a nice probability for college kids to place along information and skills. The training expertise in associate degree place affects students ${ }^{\text {ee }}$ learning outcomes and attitudes towards their future careers.

Data Analysis: There 21 Central IHM's. From these colleges total 60 students are selected at random as sample size. Questionnaires were given to them to fill. Few oral questions were also asked and then with the help of seven scale measurement the result is analysed 


\section{PARAMETERS FOR STUDY}

Table 1 Parameters defined for Study

\begin{tabular}{|l|l|l|l|l|}
\hline \multicolumn{1}{|c|}{ Parameters } & $\begin{array}{c}\text { Excellent } \\
\mathbf{5}\end{array}$ & $\begin{array}{c}\text { Best } \\
\mathbf{4}\end{array}$ & $\begin{array}{c}\text { Good } \\
\mathbf{3}\end{array}$ & $\begin{array}{c}\text { Average } \\
\mathbf{1}\end{array}$ \\
\hline Skill development & & & & \\
\hline $\begin{array}{l}\text { Practical } \\
\text { knowledge }\end{array}$ & & & & \\
\hline \hline $\begin{array}{l}\text { Support from the } \\
\text { hotels }\end{array}$ & & & & \\
\hline $\begin{array}{l}\text { Customers } \\
\text { behaviour }\end{array}$ & & & & \\
\hline $\begin{array}{l}\text { Working style } \\
\text { Satisfied with the } \\
\text { training }\end{array}$ & & & & \\
\hline $\begin{array}{l}\text { Satisfy with the } \\
\text { report given by } \\
\text { hotel }\end{array}$ & & & & \\
\hline
\end{tabular}

\section{RESULT IS GIVEN IN BELOW GRAPH}

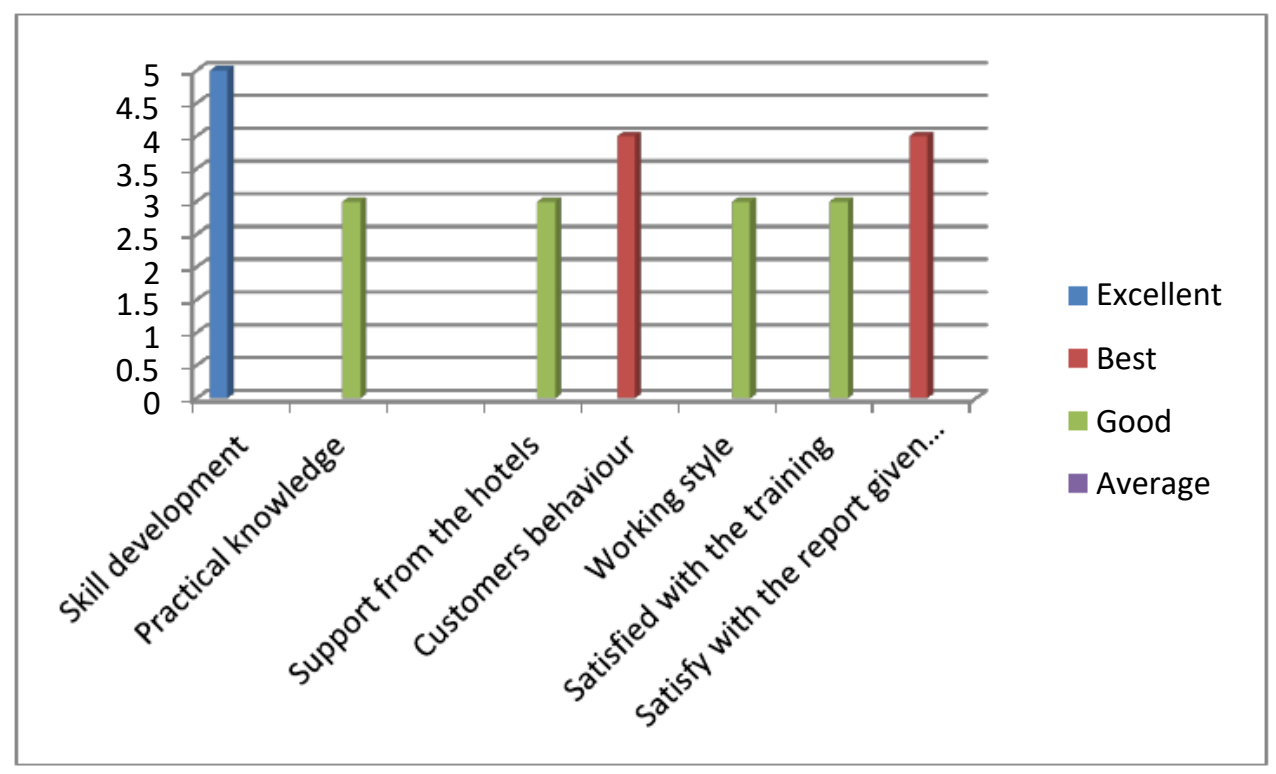

Figure 1 Graph of Result Analysis 1.0

The above graph explains the result collected from sample with the answers of questionnaire provided them.

\subsection{Benefits of Hotel Management Students in Internship}

- It will help human resource managers to improve hiring and selection practices and developing strategies to retain managers as well in career planning initiatives.

- Practical Training as an internship in Hotel Management course may help to increase the attitude of entrepreneurship amongst students.

- Students can identify the problems of hotel management during the internship. 
- It can increase the patients of the students while dealing with owner, manager, other permanent employees and customers.

\subsection{Challenges of building Management Students in Position}

- One of the foremost challenge is that to assist students brace themselves for their careers, and life, is through applying of sensible skills- be it Iindustrial Exposure internships, apprenticeships or maybe externships.

- The challenges brought by tensions between liberal and line values square measure moonfaced by all designers, deliverers, and students in instruction curricula.

- Students Stands the chance of Being Unused Prospective

- It is clear that today's young generation stand the chance of futile or delayed prospective because of uninspiring practices in firms and businesses, a risk that may be decreased with the correct initiative

- With simply a shift in perception, internships might provide students experiences that verify the remainder of their careers and also the trade and allied sectors might gain loyal and valuable talent which will facilitate form tomorrow's landscape.

- The connection of skills acquisition, and human nature/experience.

- The implications square measure necessary for production syllabus for instruction in welcome so as to work out however curricula ought to be a lot of optimally managed.

- The perception of practitioners associated educators were hierarchic consistent with the importance of preparation manager beginner competencies to organize students for an entry-level social control position within the preparation trade.

- The views of senior students and managers, each students and graduates lack confidence in their employability, significantly in areas of skilled management skills.

\section{FINDINGS}

- Business ethics has become a preferred topic in each the educational arena and also the business setting among the welcome trade.

- The restrictive body of hospitality has busy with distance education body-IGNOU for subsidisation degrees, to make a lot of confusion it's currently affiliating personal schools underneath same arrangements.

\section{SUGGESTION}

- Significant changes within the competitive setting of business and education, at the side of changes within the macro-environment, purpose to the requirement for syllabus reform in welcome management.

- To meet desire goals of the speedily the welcome trade educators should frequently investigate that competencies square measure essential for graduates to possess and revise the syllabus to fulfil these needs.

- The desired building management competencies that graduates square measure needed to possess appears to be central to the success of welcome management education.

\section{CONCLUSION}

Thus, the approach to winning, structured internships needs to be three-pronged strategy with the educational establishment, the corporate and also the student all desperate to become active, interested participants. The broader trade, beside domain, should frame and implement a berth 
policy that delivers measurable outcomes to the student's learning path. To ensure internships actually develop as important academic experiences for college students, systems have to be compelled to be place in situ that monitor and supply oversight to berth education practices among firms. Through a synergistic relationship between domain and also the trade, these systems would guarantee students get the right dose of sensible experience and learning, whereas firms, simply a couple of years down the road, get graduates United Nations agency square measure fanatical, adept and prepared to fill roles while not the necessity for extended and high-priced training. This study provides some crucial academic findings on however cordial reception educators understand the preparation of cordial reception students relative to business ethics. There are 3 distinctive findings. Feminine educators have a considerably higher level of agreement toward statements concerning business ethics within the cordial reception business than do male educators. Educators whose own level of education was an academic degree were considerably less involved concerning ethics education than educators whose own level of education was a biennial school degree or a master's degree. The role of peer assessment in managing student performance in cordial reception education problems, like responsibility and effectiveness for college kids and educators, are investigated with attention on the impacts of cluster size on the observation of peer assessment. Variations between peer assessment in teams of but 10 students and teams with 10 or additional are explored. Findings indicate differential patterns of marking supported cluster size with smaller teams tending to mark peers additional liberally than larger teams

\section{REFERENCES}

[1] Michael J, Manoharan A (2016) The Balance of Liberal and Vocational Values in Hospitality Higher Education: Voices of Graduates. Journal of Hospitality \& Tourism Education 28: 44-57.

[2] Gersh I (2016) Culinary Industry Practitioners' and Educators' Perceptions of Core Competencies for a 4-Year Bachelor's Degree in the Culinary Arts. Journal of Hospitality \& Tourism Education 28: 32-43.

[3] Wang YF, Tsai CT (2014) Employability of Hospitality Graduates: Student and Industry Perspective Journal of Hospitality \& Tourism Education Volume 26: 125-135.

[4] Zopiatis A, Constanti P (2012) Managing Hospitality Internship Practices: A Conceptual Framework. Journal of Hospitality \& Tourism Education 24: 44-51.

[5] Millar M, Mao Z (2010) Hospitality \& Tourism Educators vs. The Industry: A Competency Assessment. Journal of Hospitality \& Tourism Education 2: 38-50.

[6] Johanson M, Ghiselli R, Shea LJ (2011) Changing Competencies of Hospitality Leaders: A 25Year review, Journal of Hospitality \& Tourism Education 23: 3.

[7] Christou E (2002) Revisiting Competencies for Hospitality Management: Contemporary Views of the Stakeholders. Journal of Hospitality \& Tourism Education 14: 25-32.

[8] Martin Scarrott (3 November 2009). Sport, Leisure and Tourism Information Sources. Routledge. p. 96. ISBN 978-1-136-36455-6. Retrieved 25 April 2017.

[9] "All editions for 'Hotel \& motel management"'. WorldCat. Retrieved 25 April 2017.

[10] Hadyn Ingram (7 June 2007). Business of Hotels. Routledge. p. 203. ISBN 1-136-35944-3. Retrieved 25 April 2017.

[11] Jason Fell (12 October 2010). "Questex Renames, Redesigns Hotel \& Motel Management". Folio:. Retrieved 25 April 2017.

[12] Travel and Tourism. Infobase Publishing. 2010. p. 187. ISBN 978-0-8160-8078-6. Retrieved 25 April 2017. 